\title{
Bone Morphogenetic Protein-6 Production in Human Osteoblastic Cell Lines Selective Regulation by Estrogen
}

\author{
David J. Rickard, ${ }^{\star}$ Lorenz C. Hofbauer, ${ }^{\star}$ Susan K. Bonde, ${ }^{\star}$ Francesca Gori,, ${ }^{\star}$ Thomas C. Spelsberg, ${ }^{\ddagger}$ and B. Lawrence Riggs ${ }^{\star}$
}

$*$ Endocrine Research Unit and ${ }^{\ddagger}$ Department of Biochemistry and Molecular Biology, Mayo Clinic, Rochester, Minnesota 55905

\begin{abstract}
Bone morphogenetic proteins (BMPs) induce differentiation of osteoblast and chondroblast lineage cells from uncommitted mesenchymal precursors. Because estrogen has potent osteochondrogenic actions, we investigated its effect on BMP production in two estrogen-responsive, human immortalized cell lines (hFOB/ER3 and hFOB/ER9) that display the mature osteoblast phenotype. These cell lines were produced by stable transfection of the estrogen receptor (ER) gene into immortalized fetal osteoblasts at low $(\sim 800 \mathrm{ER} /$ nucleus) and at high $(\sim 3,900 \mathrm{ER} /$ nucleus $)$ levels, respectively. As assessed by reverse transcriptase PCR, treatment with $17 \beta$-estradiol $\left(10^{-10}-10^{-7} \mathrm{M}\right)$ increased steady-state levels of BMP-6 mRNA dose dependently by twofold in the hFOB/ER3 cells and by over threefold in the hFOB/ER9 cells. Messenger RNA levels for transforming growth factors- $\beta_{1}$ and $-\beta_{2}$ and BMPs- 1 through -5 and -7 levels were unchanged. The results were confirmed by sequence determination of the PCR product and by Northern blot analysis for total RNA. 17 $\beta$-estradiol increased BMP-6 protein production sixfold by Western analysis. Cotreatment with antiestrogens (ICI 182,780 or 4-hydroxytamoxifen) antagonized the effects of $17 \beta$-estradiol. These data suggest that some of the skeletal effects of estrogen on bone and cartilage may be mediated by increased production of BMP-6 by osteoblasts. $(J$. Clin. Invest. 1998. 101:413-422.) Key words: osteoblasts • differentiation • antiestrogens $\bullet$ estrogen $\bullet$ BMP
\end{abstract}

\section{Introduction}

Estrogen has major effects on skeletal homeostasis (1). It plays a role in initiating and sustaining the adolescent growth spurt, and in the closure of the epiphyseal growth plates. In the adult, it decreases bone turnover and maintains existing skeletal mass. Estrogen has direct effects on osteoblasts $(2,3)$ and osteoclasts $(4,5)$ by acting through high affinity receptors. However, a large amount of data suggest that many of the effects of estrogen on decreasing osteoclastic activity may be mediated by paracrine effects of bone-active cytokines secreted by osteoblasts, including IL-1 and -6 (6, 7), tumor necrosis factor (6), and TGF- $\beta$ (8). Estrogen may also have autocrine effects on osteoblasts through increased secretion of IGF-I (9) and by increasing the level of inhibitory IGF-binding protein-4 (10).

\footnotetext{
Address correspondence to B. Lawrence Riggs, Mayo Clinic, 200 First Street SW, North 6 Plummer, Rochester, MN 55905. Phone: 507284-3961; FAX: 507-284-8271; E-mail: Riggs.Lawrence@Mayo.edu

Received for publication 18 February 1997 and accepted in revised form 11 November 1997.
}

The Journal of Clinical Investigation

Volume 101, Number 2, January 1998, 413-422

http://www.jci.org
The bone morphogenetic proteins (BMP-2 to BMP-13) ${ }^{1}$ are members of the TGF $\beta$ superfamily (BMP-1 is an unrelated but copurifying protease [11]) and were originally identified as the active factors in demineralized bone matrix that induced the ectopic formation of new cartilage and bone when implanted in adult animals $(12,13)$. The BMPs act as morphogens during embryogenesis (14). BMP-2, -4, and -6 are produced in a spatially and temporally distinct manner during limb bud development, which suggests that sequential expression of different TGF $\beta / \mathrm{BMP}$ genes may coordinate the formation of bone and cartilage $(15,16)$. Because BMP-2 was the earliest BMP detected in condensing prechondrocytic mesenchyme of developing limb buds (15) and because in vitro it induces first a chondrogenic and then an osteogenic phenotype in undifferentiated limb bud cells (17), it may be the factor that initiates the endochondral bone formation cascade. In vitro, the BMPs have been shown to induce differentiation of multipotential mesenchymal cells to the osteoblastic $(18,19)$ and chondroblastic lineages (20) and thus may play a role in bone remodeling and fracture healing. However, although many of the actions of the BMPs on osteoblast and chondroblast development are well documented, little is known about the regulation of BMP synthesis.

Because estrogen affects key aspects of bone growth and remodeling and because the BMPs represent a novel class of cytokines that modulate the growth and differentiation of osteoblastic and chondroblastic lineage cells, we tested the hypothesis that estrogen regulates the production of one or more of the BMPs by osteoblasts. We report here that estrogen selectively stimulates the production of BMP-6 in two estrogenresponsive human osteoblastic cell lines.

\section{Methods}

All materials were purchased from Sigma Chemical Co. (St. Louis, $\mathrm{MO}$ ) unless otherwise stated. Hygromycin B was obtained from ICN Biochemicals Inc. (Aurora, $\mathrm{OH}$ ) and geneticin disulfate, G418, was from Gibco BRL (Gaithersburg, MD). Radioisotopes were obtained from New England Nuclear (Boston, MA). Tissue culture plasticware was purchased from Corning (Corning, NY). The pure antiestrogen ICI 182,780 was generously provided by Zeneca Pharmaceuticals (Macclesfield, United Kingdom).

Cell culture. The hFOB/ER3 and -9 cell lines were produced in our laboratories by stable transfection of the hFOB1.19 human fetal osteoblast cell line (21) with an expression vector containing the wildtype human ER gene (ER) (22). Both cell lines closely resemble the phenotype of the mature osteoblast except that they have a blunted increase in cAMP after PTH treatment and do not increase TGF $\beta$ production after estrogen treatment (unpublished data). The FOB/ ER3 and -9 cell lines contain $\sim 800$ and 3,900 functional ER/nucleus, respectively, which are within the lower part of the physiologic range

1. Abbreviations used in this paper: BMP, bone morphogenetic protein; ER, estrogen receptor; GAPDH, glyceraldehyde 3-phosphate dehydrogenase; RT-PCR, reverse transcriptase PCR. 
of ER concentrations for both bone and reproductive tissue. Human osteoblastic cells from orthopedic surgical waste bone contained a mean 1,615 functional ER/nucleus (3). Human reproductive tissue (breast and endometrium) contain between 3,000 to 9,000 functional ER/nucleus $(23,24)$. Treatment of the FOB/ER cells with $17 \beta$-estradiol increased osteoblast differentiation (25) and induced expression of progesterone receptor, a characteristic feature of estrogen responsive tissue (22). Both cell lines were cultured in a 1:1 (vol/vol) mixture of phenol red-free DME and Ham's F-12 medium supplemented with $10 \%(\mathrm{vol} / \mathrm{vol})$ FBS that had been depleted of steroids by dextran/ charcoal treatment. Medium containing either hygromycin B (100 $\mu \mathrm{g} / \mathrm{ml})$ or geneticin sulfate $(300 \mu \mathrm{g} / \mathrm{ml})$ was used alternately every $2 \mathrm{~d}$ for the continuous selection of cells that express both the temperature-sensitive (tsA58) T antigen gene and the ER gene, as described (22). Cells were incubated in a humidified atmosphere of $5 \% \mathrm{CO}_{2} /$ $95 \%$ air at $34^{\circ} \mathrm{C}$, the permissive temperature for the mutant $\mathrm{T}$ antigen protein. For each analysis, the cells were passaged into $10-\mathrm{cm}$ tissue culture dishes, grown in selective medium until near confluence, and then pretreated for $48 \mathrm{~h}$ with the "pure" antiestrogen ICI 182,780 at $10^{-8} \mathrm{M}$ in medium containing $10 \%(\mathrm{vol} / \mathrm{vol})$ steroid-depleted FBS to abolish the actions of residual estrogen (26). After this pretreatment, the cell layers were washed twice with PBS before addition of $17 \beta$ estradiol $\left(17 \beta-E_{2}\right)$, ICI 182,780 , or vehicle in DME/Ham's F-12 medium containing $0.1 \%(\mathrm{wt} / \mathrm{vol})$ BSA. The cell-conditioned medium was collected and RNA was extracted from cell layers at the times indicated in the text and figure legends. All experiments were performed at $34^{\circ} \mathrm{C}$ except when stated otherwise.

Because many of the TGF $\beta / B M P$ superfamily genes were originally isolated and cloned from the U2-OS human osteosarcoma cell line $(12,27)$, this cell line was used as a positive control for the expression of each gene analyzed. U2-OS cells were cultured in phenol red-free DME/Ham's F-12 medium supplemented with $10 \%$ (vol/vol) heat-inactivated FBS, penicillin $(100 \mathrm{U} / \mathrm{ml})$ and streptomycin $(100$ $\mu \mathrm{g} / \mathrm{ml}$ ) and were grown in a humidified atmosphere of $95 \%$ air $/ 5 \%$ $\mathrm{CO}_{2}$ at $37^{\circ} \mathrm{C}$.

$R N A$ extraction, $c D N A$ synthesis, and reverse transcriptase $P C R$ $(R T-P C R)$. RNA was extracted from hFOB/ER3, hFOB/ER9, and U2-OS cells cultured in $10-\mathrm{cm}$ dishes by the method of Chomczynski and Sacchi (28). cDNA was synthesized from $4 \mu \mathrm{g}$ of total RNA in a $20-\mu l$ reaction mixture containing $1 \times$ reverse transcriptase buffer $\left(10 \mathrm{mM} \mathrm{MgCl}_{2}, 50 \mathrm{mM} \mathrm{KCl}, 50 \mathrm{mM}\right.$ Tris- $\mathrm{HCl}$ at $\mathrm{pH} 8.3,10 \mathrm{mM}$ DTT, $0.5 \mathrm{mM}$ spermidine [Promega Corp., Madison, WI]), dCTP, dGTP, dATP, and dTTP each at $2 \mathrm{mM}$ (Boehringer Mannheim, Indianapolis, IN), $20 \mathrm{U}$ of RNase inhibitor (Promega Corp.), 8-10 U of AMV reverse transcriptase (Promega Corp.), 200 pmol of random hexamer primer, and 50 pmol of poly-dT15 primer (Boehringer Mannheim). Reaction time was at least $3 \mathrm{~h}$ at $42^{\circ} \mathrm{C}$.

Aliquots $(4 \%)$ of the total cDNA were amplified in each PCR in a $20-\mu \mathrm{l}$ reaction mixture that contained $5 \mathrm{pmol}$ of $5^{\prime}$ and $3^{\prime}$ primers, $1 \times$ PCR buffer $(50 \mathrm{mM} \mathrm{KCl}, 10 \mathrm{mM}$ Tris- $\mathrm{HCl}$ at $\mathrm{pH} 9.0,0.1 \%$ (vol/ vol) Triton X-100 [Promega Corp.]), dCTP, dGTP, dATP and dTTP each at $0.2 \mathrm{mM}, 1.5 \mathrm{mM} \mathrm{MgCl}_{2}, 0.25 \mu \mathrm{l}$ of $\left(\left[\alpha^{32} \mathrm{P}\right] \mathrm{dCTP}[10 \mu \mathrm{Ci} / \mu \mathrm{l}]\right)$, and $0.5 \mathrm{U}$ of Taq polymerase (Promega Corp. or Perkin-Elmer, Norwalk, CT). To improve sensitivity in PCR for TGF/BMP genes, Taq Start antibody was included in the reaction mixture according to the manufacturer's (Clontech Laboratories Inc., Palo Alto, CA) instructions. Each cDNA sample was run in duplicate for every PCR. The same reaction profile was used for all primer sets: an initial denaturation at $94^{\circ} \mathrm{C}$ for $2 \mathrm{~min}$ and then cycles of $94^{\circ} \mathrm{C}$ for $30 \mathrm{~s}, 55^{\circ} \mathrm{C}$ for $2 \mathrm{~min}$, and $72^{\circ} \mathrm{C}$ for $2 \mathrm{~min}$. Amplification reactions specific for the following cDNAs were performed: TGF $\beta_{1}$ and $-\beta_{2}$, BMPs $1-7$, and the housekeeping gene glyceraldehyde 3-phosphate dehydrogenase (GAPDH). The PCR primer sequences are given in Table I. The reactions were performed in a GeneAmp 9600 thermal cycler (Perkin-Elmer), typi-

Table I. Oligodeoxynucleotide Primers Used in the PCR

\begin{tabular}{|c|c|c|c|}
\hline Target cDNA & Primer sequence $\left(5^{\prime}-3^{\prime}\right)$ & Location within gene sequence & Product size \\
\hline & & & $b p$ \\
\hline \multirow[t]{2}{*}{ TGF- $\beta_{1}$} & 5': GCCCTGGACACCAACTATTGC & Mature & 338 \\
\hline & 3': TCAGCTGCACTTGCAGGAGC & Mature & \\
\hline \multirow[t]{2}{*}{ TGF- $\beta_{2}$} & 5': CAGCTTGTGCTCCAGACAGT & Propeptide & 475 \\
\hline & 3': ATATGTGGAGGTGCCATCAAT & Propeptide & \\
\hline \multirow[t]{2}{*}{ BMP-1 } & 5': AGGTACAGCAGGCTGTGGAT & Domain A & 562 \\
\hline & 3': AGGCTCCATCTTCAGGAAGTT & Domain A & \\
\hline \multirow[t]{2}{*}{ BMP-2 } & 5': TTGCGGCTGCTCAGCATGTT & Propeptide & 315 \\
\hline & 3': CATCTTGCATCTGTTCTCGGAA & Propeptide & \\
\hline \multirow[t]{2}{*}{ BMP-3 } & 5': AGGTCTCTGAACACATGCTG & Propeptide & 623 \\
\hline & 3': GGTGTCCCTGTAAGCTTGAT & Propeptide & \\
\hline \multirow[t]{2}{*}{ BMP-4 } & 5': GACCTATGGAGCCATTCCGTA & $5^{\prime}$ untranslated & 397 \\
\hline & 3': TCAGGGATGCTGCTGAGGTT & Propeptide & \\
\hline \multirow[t]{2}{*}{ BMP-5 } & 5': AGCCGTCTTCTGCTACATCA & $5^{\prime}$ untranslated & 397 \\
\hline & 3': CTGGAGTGAACATGATTGTCT & Propeptide & \\
\hline BMP-6 & 5': TGGTCTGTAGCAAGCTGAGTT & $3^{\prime}$ untranslated & 458 \\
\hline (noncoding) & 3': GAGTACAGCAAATGGAGGATT & $3^{\prime}$ untranslated & \\
\hline BMP-6 & 5': ACATGGTCATGAGCTTTGTGA & Propeptide & 528 \\
\hline (coding) & 3': GTAGAGCGATTACGACTCTGT & Mature & \\
\hline \multirow[t]{2}{*}{ BMP-7 } & 5': CAGCCTGCAAGATAGCCATT & Propeptide & 276 \\
\hline & 3': GAGCAGGAAGAGATCCGATT & Propeptide & \\
\hline \multirow[t]{2}{*}{ GAPDH } & 5': ACCACAGTCCATGCCATCAC & - & 451 \\
\hline & 3': TCCACCACCCTGTTGCTGTA & - & \\
\hline
\end{tabular}

For the majority of TGF/BMP genes, the primers were designed to the propeptide or noncoding regions where sequence homology with the other superfamily members is less than within the mature domain. 


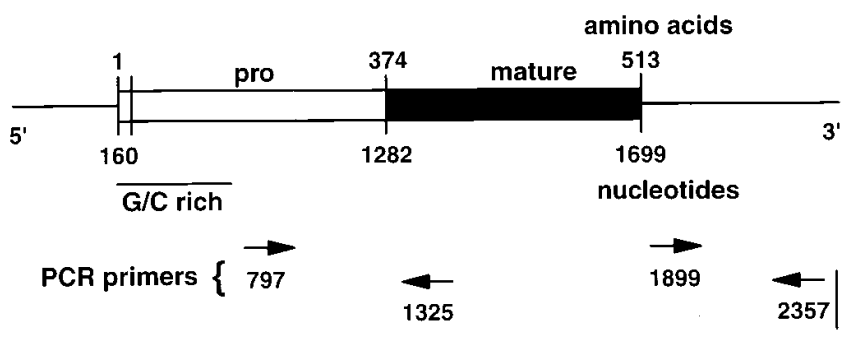

Figure 1. Schematic diagram of human BMP-6 showing positions of the PCR primers. Numbers denote amino acid position (above) and nucleotide position (below) according to accession \# M38694 of the GenBank data base (see reference 27). The cDNA has an open reading frame of 1,539 bp and encodes a 513-amino acid propeptide that is cleaved to give the mature (biologically active) 139-amino acid $\mathrm{COOH}$-terminal protein. Arrows represent the positions of primers used in PCR and their 5'-3' orientation.

cally for 30-35 cycles depending on the product intensity. To ensure greater accuracy in quantitation of cDNAs for BMP-6 and GAPDH, amplification reaction profiles for these were initially determined so that subsequent reactions could be terminated during the linear phase of amplification: after 34 and 24 cycles for BMP-6 and GAPDH, respectively.

Reaction products were analyzed by electrophoresis in $1.5 \%$ (wt/ vol) agarose gels. The amplified DNA fragments were visualized by ethidium bromide staining and quantified by measuring the radioactivity in gel slices. Quantitative differences between cDNA samples were calculated after normalizing for the radioactivity present in the corresponding GAPDH PCR product. The coefficients of variation for duplicate measurements of the more readily detectable TGF $\beta /$ BMP mRNAs by RT-PCR in the presence of the TaqStart antibody, and of GAPDH, were calculated to be between 2 and $10 \%$.

Two sets of PCR primers were used in RT-PCR for BMP-6: primers 1899/2357 amplified part of the $3^{\prime}$ untranslated region, and primers 797/1325 amplified a fragment from both propeptide and mature region coding sequences (Fig. 1).

Synthesis and sequence determination of BMP-6 cDNA probes. BMP-6 primer sets $1899 / 2357$ and 797/1325 were used in two-step PCRs to generate cDNA probes comprising sequences from the $3^{\prime}$ untranslated region and part of the coding region, respectively (see Fig. 1). These cDNA fragments were subsequently used as probes in Northern blot analysis (see below). In the first round PCR, each primer set was used to amplify sequences from U2-OS cDNA in the presence of the TaqStart antibody, and aliquots of the first round PCR were then diluted 1:10 and amplified again in a second round of PCR using the same primer set. Products from 20-s round reactions were pooled and electrophoresed on $1 \%$ (wt/vol) low-melting point agarose gels, the band of the correct size was excised, and the DNA was purified using the Wizard PCR DNA purification kit (Promega Corp.).

For sequence analysis, $\sim 60 \mathrm{ng}$ of each purified cDNA fragment was added to $3.2 \mathrm{pmol}$ of either $5^{\prime}$ or $3^{\prime}$ primer and analyzed in both directions by using Ampli-Taq FS DNA polymerase (Applied Biosystems Inc., Foster City, CA) in an automated DNA sequence analyzer.

Northern blot hybridization. Steady state mRNA levels were quantified by Northern blot hybridization analysis. Poly (A) ${ }^{+}$RNA was isolated from $\mathrm{hFOB} / \mathrm{ER} 3, \mathrm{hFOB} / \mathrm{ER}$, and U2-OS cells using the Micro Fast-Track mRNA isolation kit according to the manufacturer's instructions (Invitrogen Corp., San Diego, CA). Poly (A) ${ }^{+}$ RNA $(1.5-7 \mu \mathrm{g})$ was denatured in glyoxal buffer at $50^{\circ} \mathrm{C}$ for $1 \mathrm{~h}$ and electrophoresed on $1 \%(\mathrm{wt} / \mathrm{vol})$ agarose gels with $0.01 \mathrm{M} \mathrm{Na}_{2} \mathrm{HPO}_{4}$, $\mathrm{pH} 6.5$ as circulating buffer. The RNA was transferred to nylon mem- branes (HyBond-N; Amersham Corp., Arlington Heights, IL) by downward alkaline blotting with $3 \mathrm{M} \mathrm{NaCl}, 8 \mathrm{mM} \mathrm{NaOH}$ for $3 \mathrm{~h}$. Membranes were hybridized overnight at $42^{\circ} \mathrm{C}$ to ${ }^{32} \mathrm{P}$-labeled DNA probes in Hybridsol (Oncor, Gaithersburg, MD) hybridization buffer $(6 \times \mathrm{SSC}, 50 \%$ [vol/vol] formamide, $10 \%$ [wt/vol] dextran sulfate, and $1 \%$ [wt/vol] SDS).

Double-labeled BMP-6 probes were synthesized from $60 \mathrm{ng}$ of purified BMP-6 DNA fragment (generated by PCR, see above) with 100 pmol of the appropriate 3' PCR primer (primer 2357 or 1325), 50 $\mu \mathrm{Ci}$ each of $\left[\alpha{ }^{3}{ }^{32} \mathrm{P}\right] \mathrm{dCTP}$ and $\left[\alpha-{ }^{32} \mathrm{P}\right] \mathrm{dATP}(10 \mu \mathrm{Ci} / \mu \mathrm{l})$, and $2 \mathrm{U}$ of Klenow fragment (Ambion Inc., Austin, TX) in reaction buffer $(5 \mathrm{mM}$ $\mathrm{MgCl}_{2}, 10 \mathrm{mM}$ Tris- $\mathrm{HCl}, 7.5 \mathrm{mM}$ DTT, $20 \mu \mathrm{M}$ dGTP, and $20 \mu \mathrm{M}$ dTTP). Labeling reactions were performed for $2 \mathrm{~h}$ at $37^{\circ} \mathrm{C}$. The DNA probes were separated from unincorporated nucleotides on Sephadex G-50 spin columns (Pharmacia Biotechnology Inc., Piscataway, NJ) and had a specific activity of $>10^{9} \mathrm{cpm} / \mu \mathrm{g}$ DNA. The $\beta$-actin DNA probes were synthesized from $50 \mathrm{ng}$ of a 27-nucleotide fragment of $\beta$-actin cDNA (Clontech Laboratories Inc.) using a Decaprime II random priming labeling kit (Ambion Inc.) and $50 \mathrm{mCi}\left[\alpha{ }^{32} \mathrm{P}\right] \mathrm{dCTP}$ to a specific activity of $>10^{8} \mathrm{cpm} / \mu \mathrm{g}$ DNA.

After hybridization, the membranes were washed in $2 \times \mathrm{SSC} /$ $0.1 \%$ (wt/vol) SDS for $20 \mathrm{~min}$ at $37^{\circ} \mathrm{C}$ and then in $0.1 \times \mathrm{SSC} / 0.1 \%(\mathrm{wt} /$ vol) SDS for $30 \mathrm{~min}$ at $37^{\circ} \mathrm{C}$ (for BMP-6 probes) or $55^{\circ} \mathrm{C}$ (for $\beta$-actin probes). The extent of hybridization to membranes was determined by autoradiography with x-ray film (XOMAT; Eastman Kodak Co., Rochester, NY) on intensifying screens at $-80^{\circ} \mathrm{C}$.

Western blot analysis. To estimate the amount of secreted BMP-6, Western blot analysis was performed using an anti-human BMP-6 $\mathrm{mAb}$. After 24-h treatment with ICI $182,780\left(10^{-6} \mathrm{M}\right)$ followed by 48 -h treatment in serum-free medium with $17 \beta-\mathrm{E}_{2}\left(10^{-8} \mathrm{M}\right)$, ICI 182,780 $\left(10^{-7} \mathrm{M}\right), 4$-hydroxytamoxifen $\left(10^{-8} \mathrm{M}\right)$, and $17 \alpha-\mathrm{E}_{2}\left(10^{-8} \mathrm{M}\right), \mathrm{hFOB} /$ ER9 cell-conditioned media were concentrated by $\sim 10$-fold using centriprep-3 concentrators (Amicon Inc.). Aliquots of cell-conditioned media corresponding to $50 \mu \mathrm{g}$ protein (determined by the Bradford method) were suspended in electrophoresis buffer (29) and electrophoresed in SDS-PAGE (12.5\% [ $\mathrm{vol} / \mathrm{vol}])$ under reducing conditions, using protein mixture (Amersham Corp.) as standards. The blots were then electrotransferred for $30 \mathrm{~min}$ onto a nitrocellulose membrane (Schleicher \& Schuell, Keene, NH). All subsequent steps were performed at room temperature. The blots were blocked for $2 \mathrm{~h}$ in PBS ( $\mathrm{pH} 7.4$ ) containing $0.3 \%$ (wt/vol) BSA (blocking buffer), washed with PBS containing $0.1 \%$ (vol/vol) Tween 20 and probed with an anti-human BMP- $6 \mathrm{mAb}(1 \mu \mathrm{g} / \mathrm{ml}$ in blocking solution $)$. The anti-BMP-6 mAb, Ab h1b5/1.8.5, was raised against the mature region of rhBMP-5 but reacts equally well in Western analysis to mature BMP- 6 but not to BMP-2, -4, or -7. Recombinant human BMP-6 served as a control. The blots were then washed twice with PBS/ Tween 20 and incubated in blocking buffer for 30 min with a peroxidase-conjugated rat anti-mouse $\mathrm{IGg}_{1}$ (Biosource International, Camarillo, CA). After two washes in PBS/Tween 20 and one in PBS, immunoreactive proteins were visualized by using the ECL chemiluminescence detection kit (Amersham Corp.) according to the manufacturer's instructions. The anti-rhBMP-6 mAb and rh-BMP-6 were generous gifts from Dr. G.E. Riedel (Genetics Institute, Cambridge, MA).

Statistical analyses. The results are presented as mean \pm SE. Statistical significance between each treatment group and its controls was calculated by the two-tailed, nonpaired Student's $t$ test, and $P<$ 0.05 was considered to show statistical significance. The significance of dose-dependent changes in variables was assessed by multiple measures ANOVA.

\section{Results}

\section{RT-PCR analysis}

Constitutive expression of TGF $\beta / B M P$ MRNAs. In the hFOB/ ER9 cells, there were detectable steady state levels of TGF $\beta_{1}$ and BMP-1, -4, and -6, somewhat lower levels of $\mathrm{TGF}_{2}$ and 
A

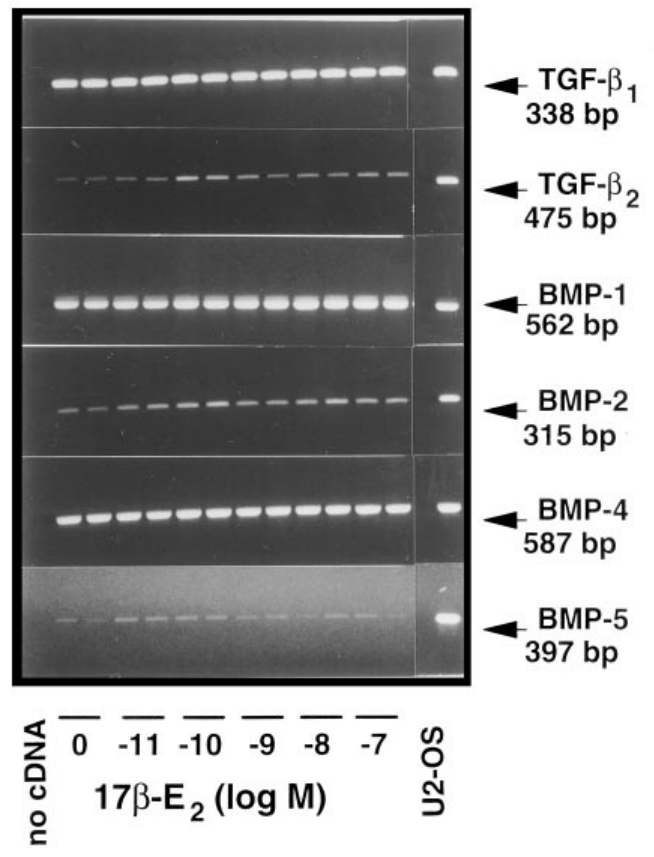

B

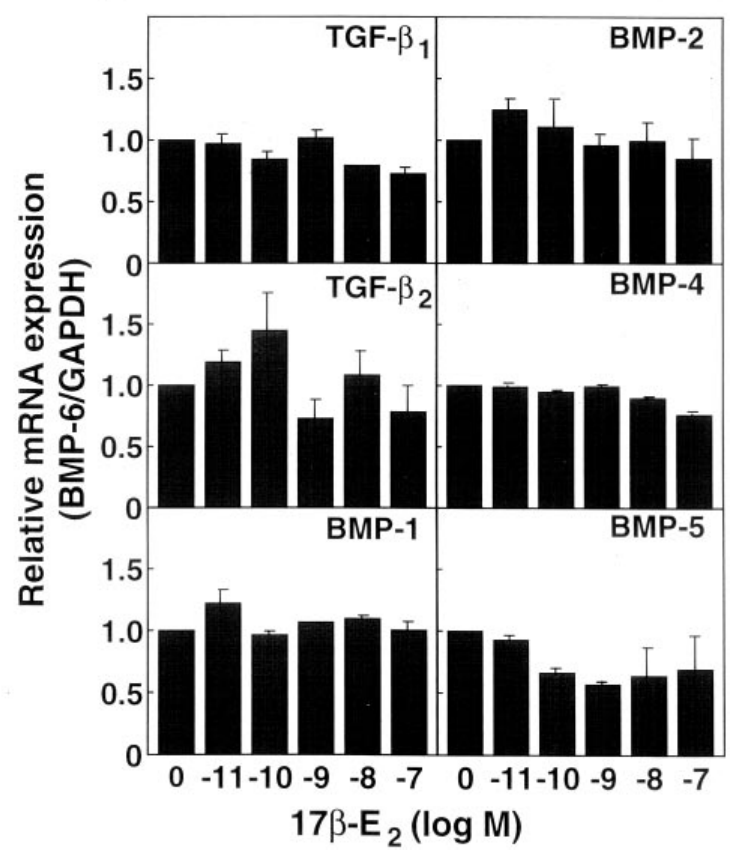

Figure 2. Lack of effect of $17 \beta$-estradiol $\left(17 \beta-E_{2}\right)$ on mRNA production for different members of the TGF $\beta / B M P$ super-

family in the hFOB/ER9 cell line. After 48-h pretreatment with ICI 182,780 cells were incubated for $24 \mathrm{~h}$ with or without $17 \beta-\mathrm{E}_{2}$ at the indicated concentrations in serum-free medium containing $0.1 \%(\mathrm{wt} / \mathrm{vol})$ BSA. Total cellular RNA was then extracted and analyzed for each gene by RT-PCR. $(A)$ Ethidium bromide-stained agarose gels of PCR products (PCR was performed in duplicate). For each gene, U2-OS cDNA was included as a positive control, and a reaction from which cDNA was omitted was used as a negative

control. The size of the PCR product is given in base pairs. $(B)$ Relative mRNA production determined from amount of radioactivity incorporated into each PCR product (measured in slices of agarose gels) and normalized to the GAPDH mRNA in the same cDNA samples. Values are mean \pm SE from two experiments.

BMP-2, barely detectable levels of BMP-3 and -5, and no detectable BMP-7 (Fig. 2). Under identical amplification conditions, expression of all of these genes was detected in the U2OS osteosarcoma cell line.

Effect of $17 \beta-E_{2}$ on $T G F \beta / B M P$ mRNA expression. After 24-h treatment of the $\mathrm{hFOB} / \mathrm{ER} 9$ cells that contained $\sim 3,900$ $\mathrm{ER} /$ nucleus with $17 \beta-\mathrm{E}_{2}$ at $10^{-11}$ to $10^{-7} \mathrm{M}$, the steady state mRNA levels for $\mathrm{TGF}_{1}$, TGF $\beta_{2}$, and BMP-1 to -5 were not different from control values (Fig. 2). In contrast, there was a reproducible stimulation of steady state levels of BMP-6 mRNA by almost threefold (Fig. $3 A$ ). This increase was dosedependent over the range of $10^{-11}$ to $10^{-8} \mathrm{M}(P<0.001)$ (Fig. $3 \mathrm{~B})$. The magnitude and concentration dependency of the $17 \beta-\mathrm{E}_{2}$ effect on BMP-6 mRNA production were similar in reactions with either a PCR primer set that amplified a 458-bp portion of the $3^{\prime}$ untranslated region of cDNA (noncoding region primers, 1899/2357) or a PCR primer set that amplified a 528-bp fragment of the coding region that contained sequences from both propeptide and mature domains (coding region primers, 797/1325; see Fig. 1). Because of the greater sequence homology between BMP-6 and the other BMPs within the coding region compared with noncoding regions, PCR with the coding region primers produced minor amplification products not seen in PCR with the $3^{\prime}$ untranslated region primers (Fig. $3 \mathrm{~A}$ ). Estrogen treatment of $\mathrm{hFOB} / \mathrm{ER} 9$ cells at the restrictive temperature $\left(39^{\circ} \mathrm{C}\right)$ exerted an identical stimulation of BMP-6 mRNA expression (Fig. $3 \mathrm{C}$ ). This shows that regulation of BMP-6 mRNA by estrogen occurs independently of active SV40 large T antigen expression.

The $\mathrm{hFOB/ER3}$ cell line that contained $\sim 800 \mathrm{ER} /$ nucleus also responded to $17 \beta-\mathrm{E}_{2}$ treatment with a dose-dependent increase over the range $10^{-11}$ to $10^{-8} \mathrm{M}(P<0.001)$ in BMP-6
mRNA (Fig. $4 A$ ). The dose response of the increase in BMP-6 mRNA was very similar to that observed in the hFOB/ER9 cell line (Fig. 4 B). However, after normalization for the GAPDH mRNA level, maximal stimulation was about twofold in the $\mathrm{hFOB} / \mathrm{ER} 3$ cells compared with about threefold in the hFOB/ER9 cells.

Sequence analysis of PCR products. To exclude the possibility that the PCR primers for BMP-6 were amplifying a sequence(s) other than BMP-6, the amplification products generated by both sets of primers were subjected to sequence analysis from their $3^{\prime}$ and $5^{\prime}$ termini. The derived sequences for both products covered between 300 and 400 nucleotides (not shown) and were found to be $>99 \%$ identical to the corresponding sequences of human BMP-6 as listed in the GenBank data base (accession number M38694 [reference 27]). Furthermore, no other sequences in the data base showed significant homology to the $3^{\prime}$ untranslated region of BMP-6 that was amplified in the PCR.

Effect of antiestrogens on constitutive and estrogen-stimulated BMP-6 $m R N A$ expression. As determined by RT-PCR after a 24-h treatment period, the "pure" estrogen antagonist ICI 182,780 alone had no effect on the constitutive BMP-6 mRNA level, whereas 4-hydroxytamoxifen alone decreased constitutive levels in hFOB/ER3 cells and acted as a weak agonist in hFOB/ER9 cells (Table II). Stimulated BMP-6 mRNA levels, induced with $10^{-9} \mathrm{M} 17 \beta-\mathrm{E}_{2}$ were inhibited in both cell lines by $10^{-7} \mathrm{M}$ 4-hydroxytamoxifen, although the inhibitory effect was more marked in hFOB/ER3 cells. At equimolar concentrations with $17 \beta-\mathrm{E}_{2}$, ICI 182,780 had little inhibitory effect on the stimulation of BMP- 6 mRNA in both hFOB/ER3 cells and $\mathrm{hFOB} / \mathrm{ER} 9$ cells. However, in $\mathrm{hFOB} / \mathrm{ER} 3$ cells ICI 182,780 at a 10 -fold molar excess to $17 \beta-E_{2}$, partially sup- 
A
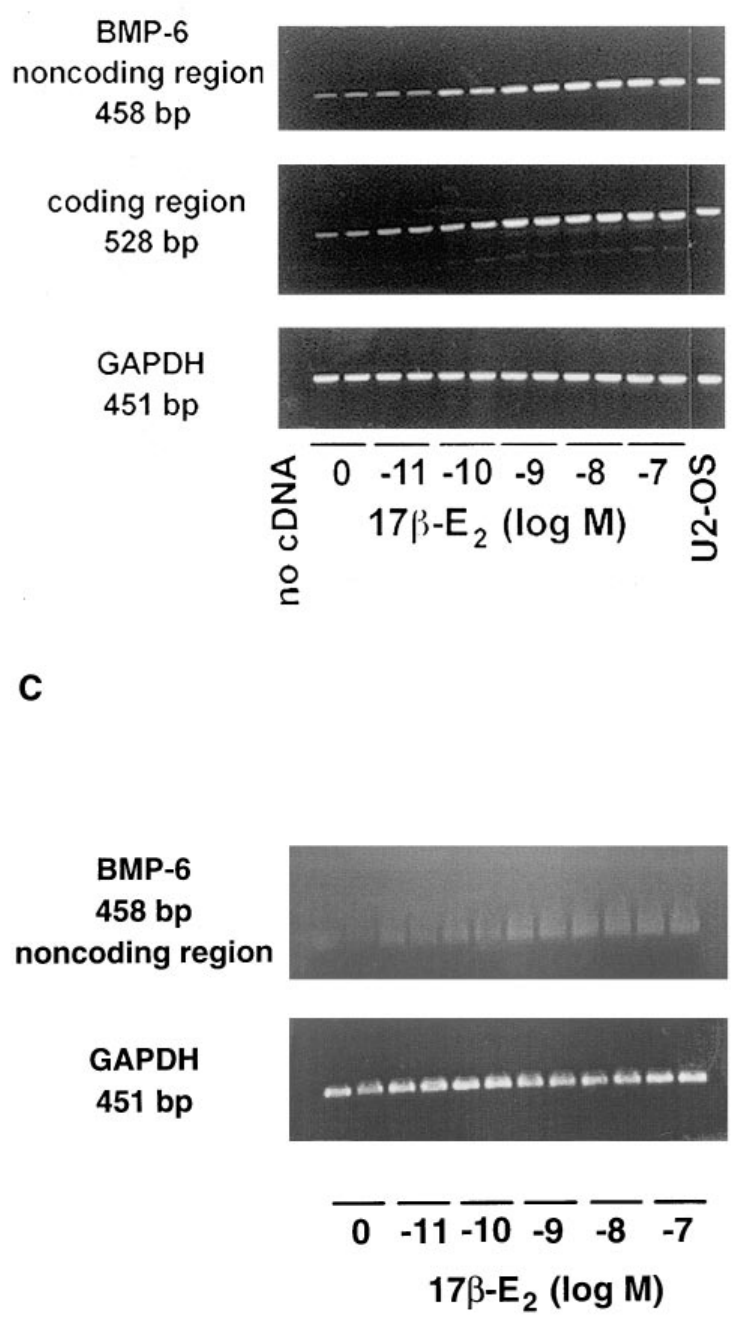

B
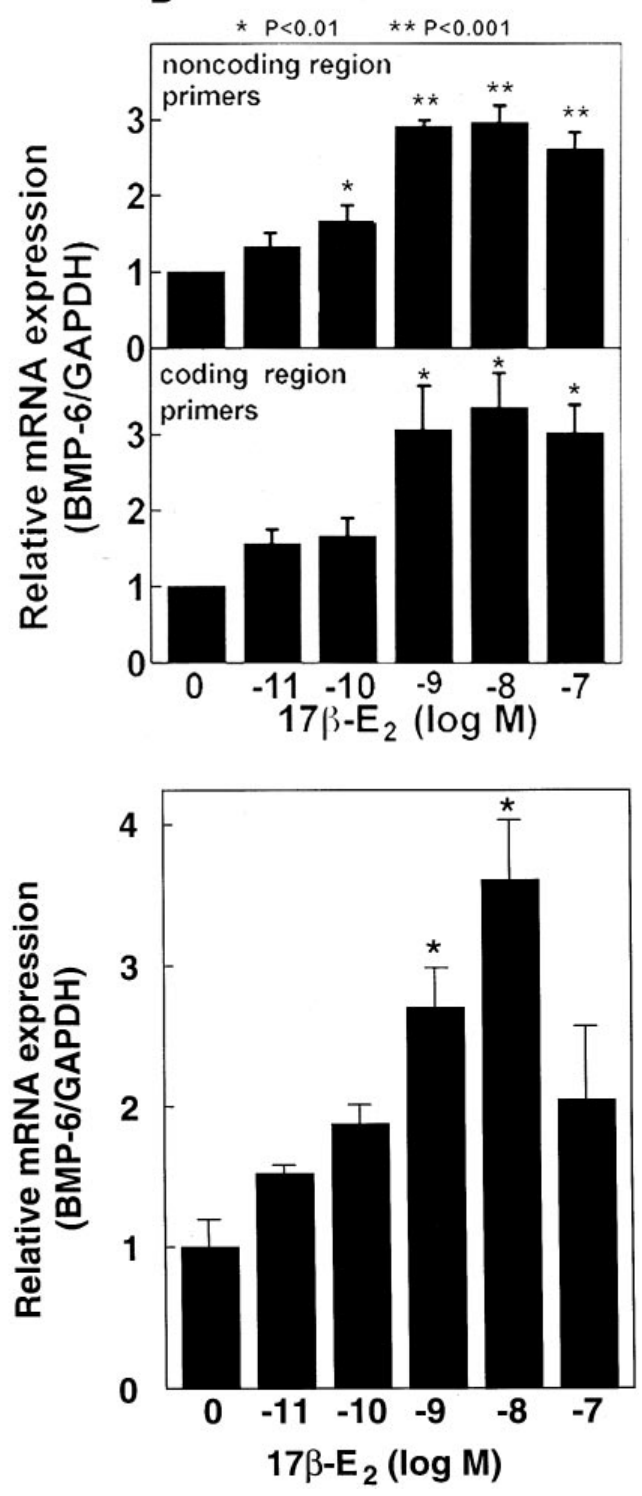

Figure 3. Stimulation of BMP-6 mRNA production by $17 \beta-E_{2}$ in the hFOB/ER9 cell line treated for $24 \mathrm{~h}$ as described in Fig. 2. $(A)$ BMP-6 cDNA fragments were amplified by PCR using primers recognizing either the $3^{\prime}$ untrans-

lated sequence (noncoding region primers, 1899/ 2357) or part of the coding region (coding region primers, 797/1325).

Shown are the PCR products from reactions with each BMP-6 primer set and primers for GAPDH after agarose gel electrophoresis and visualization with ethidium bromide. Sizes of the PCR products are given in base pairs. Radiolabeled nucleotide was incorporated into PCR products to permit direct quantification of BMP-6 mRNA expression, shown in $(B)$, as the mean $\pm \mathrm{SE}$ of three separate experiments with each primer set. $(C)$ hFOB/ER9 cells cultured and stimulated with $17 \beta-\mathrm{E}_{2}$ at the restrictive temperature, $39^{\circ} \mathrm{C}$. In PCR, BMP-6 cDNA was amplified with the coding region primers. Production has been corrected for differences in GAPDH mRNA level between samples. For significance of difference from control: $* P<0.01 ;{ }^{\ddagger} P<$ 0.001 . pressed the estrogen stimulation of BMP-6 mRNA levels and almost completely blocked the estrogen effect when added at a 100 -fold molar excess. In contrast in the hFOB/ER9 cell line, ICI 182,780 even at a 100 -fold molar excess over $17 \beta-E_{2}$, had little or no antagonistic activity. These observations are in line with the lower affinity of these antagonists compared with $17 \beta-\mathrm{E}_{2}$ for binding to ER, and also demonstrate that the increased BMP-6 synthesis is mediated through an ER-dependent mechanism. The inability of ICI 182,780 to fully antagonize the effect of estradiol in hFOB/ER9 cells may be explained by the observation that the effectiveness of different antiestrogens is highly cell specific (30). Alternatively, because ICI 182,780 was found to block estrogen stimulation of BMP-6 protein in hFOB/ER9 cells after $48 \mathrm{~h}$ treatment (see below and Fig. 8), an inhibitory effect of ICI 182,780 on BMP-6 mRNA levels in these cells may take longer than $24 \mathrm{~h}$ to become apparent. The biologically inactive stereoisomer $17 \alpha$-estradiol, added to cells at $10^{-9} \mathrm{M}$ failed to stimulate BMP-6 mRNA levels in either $\mathrm{hFOB/ER}$ cell line.

Time course of BMP-6 gene induction by $17 \beta-E_{2}$ using RT$P C R$. BMP-6 mRNA levels were found to be slightly increased after $6 \mathrm{~h}$, peaked between 12 and $24 \mathrm{~h}$, and remained high at $48 \mathrm{~h}$ after $17 \beta-\mathrm{E}_{2}$ administration (Fig. 5). These data suggest that BMP-6 is not an immediate early response gene and is unlikely to be directly regulated by estrogen, in contrast to certain protooncogenes which are maximally induced within $1 \mathrm{~h}$ after treatment (30-32).

BMP-6 $m R N A$ production in other human cell types. By RTPCR for BMP-6 mRNA with normalization for the GAPDH mRNA level, there were comparable levels of production in U2-OS osteosarcoma, HTB 94 chondrosarcoma, hFOB/ER9 cell lines, and normal osteoblast-like cells cultured from tra- 

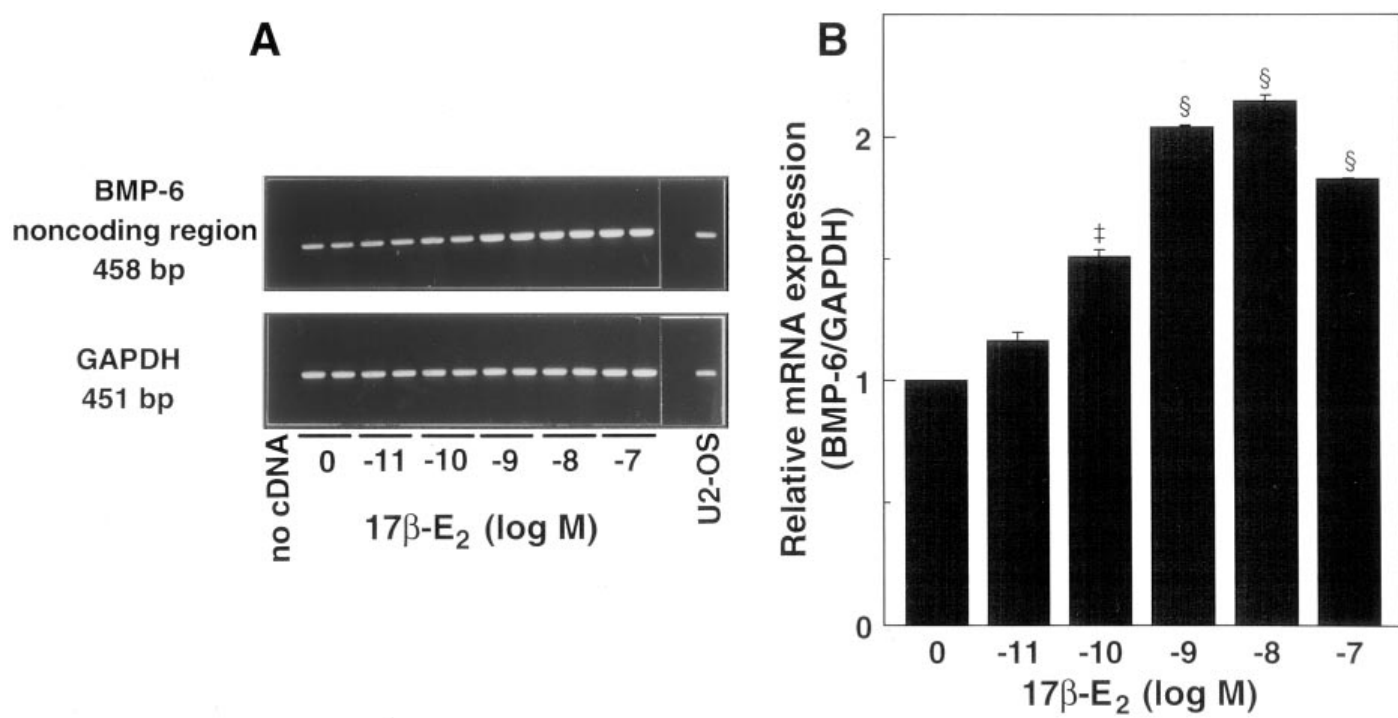

Figure 4. Estrogenmediated stimulation of BMP-6 mRNA production in the hFOB/ ER3 cell line. Cells were treated as in Fig. 2 and total RNA was extracted after $24 \mathrm{~h}$ of treatment with or without $17 \beta-\mathrm{E}_{2}$ at the concentrations shown. mRNA levels for BMP-6 and GAPDH were determined by RT-PCR using the noncoding region primers for BMP-6. (A) PCR products in ethidium bromidestained agarose gels. (B) Direct quantitation of BMP-6 mRNA levels as assessed by incor-

poration of radiolabeled nucleotide into PCR products with normalization for GAPDH mRNA. Values are the mean \pm SE of two separate experiments. For significance of difference from control: ${ }^{*} P<0.01 ;{ }^{\ddagger} P<0.001$.

becular bone explants (Fig. 6). The level of production was lower in hFOB/ER3 cells and still lower in bone marrow stroma-derived osteoblast progenitor cells.

\section{Northern blot analysis}

The coding and noncoding BMP-6 cDNA fragments generated by PCR were purified and used as radiolabeled probes in Northern analysis of hFOB/ER3 and hFOB/ER9 cell poly $(\mathrm{A})^{+}$RNA. The $3^{\prime}$ untranslated region probe hybridized to two RNA species (Fig. $7 A$ ); a larger band of $\sim 6 \mathrm{~kb}$ whose abundance was not estrogen regulated, and a smaller band of

Table II. Effect of Antiestrogens on Basal and Estrogen-stimulated BMP-6 mRNA Levels

\begin{tabular}{lcc}
\hline & \multicolumn{2}{c}{ Relative expression (BMP-6/GAPDH) } \\
\cline { 2 - 3 } \multicolumn{1}{c}{ Treatment } & \multicolumn{1}{c}{ hFOB/ER9 } & hFOB/ER3 \\
\hline Control (no treatment) & 1.00 & 1.00 \\
ICI $182,780\left(10^{-7} \mathrm{M}\right)$ & $1.111 \pm 0.153$ & $0.928 \pm 0.003$ \\
$4-\mathrm{OH}$ tamoxifen $\left(10^{-7} \mathrm{M}\right)$ & $1.431 \pm 0.117$ & $0.678 \pm 0.054$ \\
$17 \alpha-\mathrm{E}_{2}\left(10^{-9} \mathrm{M}\right)$ & $1.364 \pm 0.127$ & $1.016 \pm 0.067$ \\
$17 \beta-\mathrm{E}_{2}\left(10^{-9} \mathrm{M}\right)$ & $2.355 \pm 0.127$ & $1.850 \pm 0.278$ \\
$17 \beta-\mathrm{E}_{2}\left(10^{-9} \mathrm{M}\right)+4-\mathrm{OH}$ & & \\
$\quad$ tamoxifen $\left(10^{-7} \mathrm{M}\right)$ & $1.659 \pm 0.141(51.4)$ & $1.026 \pm 0.213(96.9)$ \\
ICI $182,780\left(10^{-9} \mathrm{M}\right)$ & $2.390 \pm 0.045(-2.6)$ & $1.630 \pm 0.720(25.9)$ \\
ICI $182,780\left(10^{-8} \mathrm{M}\right)$ & $2.038 \pm 0.114(23.4)$ & $1.422 \pm 0.410(50.4)$ \\
ICI $182,780\left(10^{-7} \mathrm{M}\right)$ & $1.960 \pm 0.194(29.2)$ & $1.111 \pm 0.033(86.9)$ \\
& &
\end{tabular}

Cells were pretreated with ICI 182,780 as described in the Methods and then incubated with the steroids and antiestrogens in serum-free medium at the concentrations shown. BMP-6 mRNA levels in 24-h RNA extracts were quantitated by RT-PCR using the noncoding region primers with normalization to GAPDH. Values are the mean \pm SE of two (FOB/ER3) and three (FOB/ER9) experiments. Numbers in parentheses represent the mean percent inhibition compared with $17 \beta-\mathrm{E}_{2}$ alone. $\sim 4.5 \mathrm{~kb}$ which was increased dramatically from almost undetectable levels by $24-\mathrm{h}$ treatment with $10^{-8} \mathrm{M} 17 \beta-\mathrm{E}_{2}$. The cDNA probe from the coding region, however, only hybridized to the $4.5 \mathrm{~kb}$ RNA band (Fig. $7 \mathrm{~B}$ ). The noncoding region probe hybridized to a single band of $\sim 2.6 \mathrm{~kb}$ in mRNA extracts from U2-OS cells (not shown). Hybridization to a cDNA probe of the housekeeping gene $\beta$-actin demonstrated approximately equal RNA loading of control and $17 \beta-E_{2}-$ treated samples (Fig. $7 C$ ). The 6-kb RNA species recognized by the

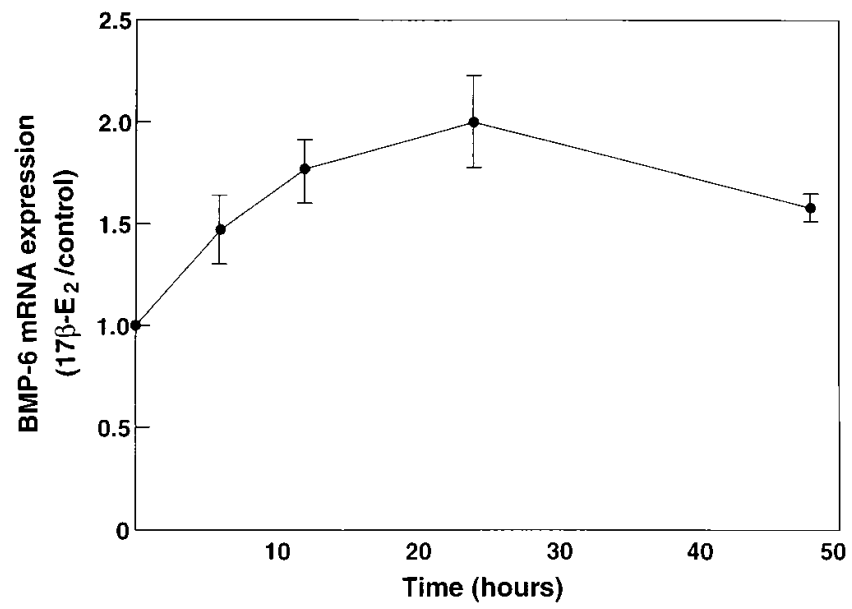

Figure 5. Time course of induction of BMP-6 mRNA production in $\mathrm{hFOB} / \mathrm{ER} 9$ cells stimulated with $17 \beta-\mathrm{E}_{2}$. Cells were pretreated with ICI 182,780 and cultured in the presence or absence of $10^{-8} \mathrm{M} 17 \beta-\mathrm{E}_{2}$ under serum-free conditions. Total RNA was extracted from control and $17 \beta-\mathrm{E}_{2}$-treated cells at $0,6,12,24$, and $48 \mathrm{~h}$ after the start of treatment. BMP-6 mRNA levels were determined by RT-PCR using the noncoding region primers. Results are expressed as a ratio of the BMP-6 mRNA level in stimulated cells compared to that in the control. BMP-6 mRNA production was normalized for GAPDH mRNA. Ratio represent the mean $\pm \mathrm{SE}$ of three experiments. 


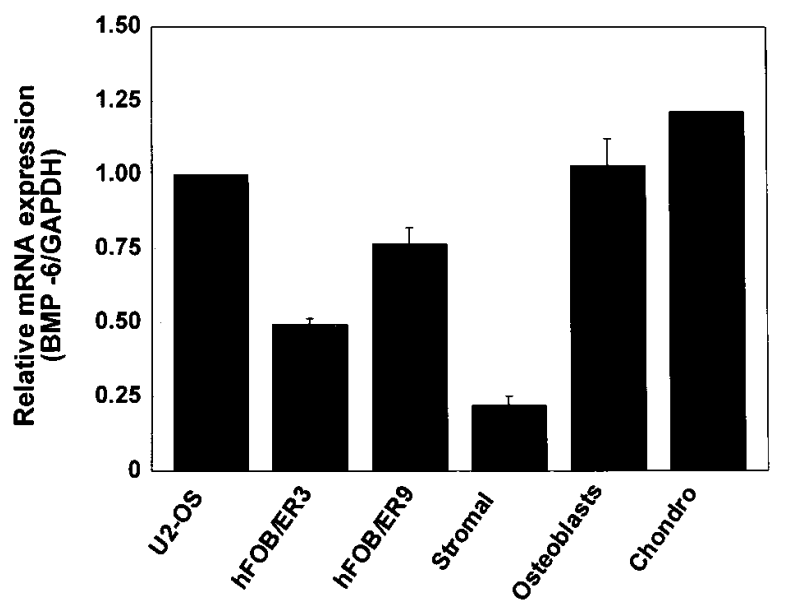

Figure 6. Comparison of BMP-6 mRNA levels in different cell types. Total RNA was extracted from untreated confluent cultures of the following human primary cell cultures and cell lines: U2-OS osteosarcoma, $\mathrm{hFOB} / \mathrm{ER} 3$ and $\mathrm{hFOB} / \mathrm{ER} 9$, fibroblastic bone marrow stromal cells (stromal), differentiated trabecular bone-derived osteoblast-like cells (osteoblasts), and HTB 94 chondrosarcoma (chondro). BMP-6 mRNA levels were determined by RT-PCR using the noncoding region BMP-6 primers. Results are presented as the mean $\pm \mathrm{SE}$ of two separate experiments using different primary cultures. Values for BMP-6 mRNA production have been corrected for differences in GAPDH mRNA levels between samples.

noncoding region BMP-6 probe is believed to be residual $28 \mathrm{~S}$ ribosomal RNA in the mRNA preparation, because preliminary analysis of total cellular RNA revealed cross-reactivity of this probe to 28S RNA (not shown). The size of the mRNA for BMP-6 detected in hFOB/ER cell lines is in agreement with other reports $(33,34)$. Densitometry of autoradiograms and normalization to $\beta$-actin showed that estrogen stimulated BMP-6 mRNA levels by 2.4-fold in hFOB/ER9 cells and by 6.3 -fold in hFOB/ER3 cells. The greater induction in hFOB/ ER3 cells compared to hFOB/ER9 cells was opposite to that demonstrated by the RT-PCR and, consequently, it is uncertain whether one cell line exhibits a greater induction of BMP-6 mRNA expression after estradiol treatment than the other.

\section{Western blot analysis}

Secretion of BMP-6 protein was assessed by Western blot analysis of conditioned medium from cultured hFOB/ER9 cells (Fig. 8). Under reducing conditions the monoclonal antiBMP-6 antibody detected a major immunoreactive band migrating at $\sim 25 \mathrm{kD}$ and a minor species of $\sim 15 \mathrm{kD}$. Recombinant human BMP-6, loaded as a positive control, comigrated with the major band. BMP-6 is synthesized as a disulfidelinked homodimer of $\sim 125 \mathrm{kD}$ which is cleaved before secretion into propeptide fragments and the biologically active homodimer of the mature region. The latter is a differentially glycosylated homodimer with a molecular weight of $\sim 45 \mathrm{kD}$ $(35,36)$. As the antibody used recognized only the mature regions of BMP-5 and BMP-6, under reducing conditions the major band most probably represents the glycosylated mature region monomer, and the minor band may be the unglycosylated form. The bands are believed to be BMP-6 rather than BMP-5 because the mRNA level for BMP-5 in hFOB/ER9 cells was barely detectable by RT-PCR. As assessed by densitometry,

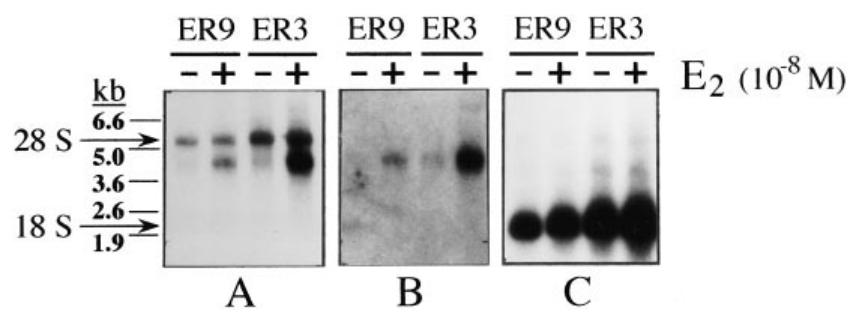

Figure 7. Northern blot analysis of BMP-6 mRNA. Both hFOB/ER cell lines were identically treated; pretreatment with ICI 182,780 was followed by a 24-h incubation with ethanol vehicle (control) or $10^{-8} \mathrm{M}$ $17 \beta-E_{2}$ in serum-free medium. Poly (A) ${ }^{+}$RNA was extracted from cell pellets and $3 \mu \mathrm{g}$ (hFOB/ER9) and $7 \mu \mathrm{g}$ (hFOB/ER3) quantities electrophoresed, transferred to nylon membranes, and hybridized to ${ }^{32} \mathrm{P}$-labeled cDNA probes. $(A)$ Autoradiogram of hybridization with the $3^{\prime}$ untranslated region probe of BMP- $6 ;(B)$ the coding region probe of BMP- 6 ; and $(C) \beta$-actin, for the evaluation of differences in sample loading. The numbers on the left indicate the position of RNA size markers, in kilobases, and the migration of $28 \mathrm{~S}$ and $18 \mathrm{~S}$ ribosomal RNA.

$17 \beta-\mathrm{E}_{2}$ at $10^{-8} \mathrm{M}$ induced a sixfold increase in the concentration of BMP- 6 as compared with vehicle alone. There was no stimulation with the weak estrogen isomer, $17 \alpha-\mathrm{E}_{2}$ at $10^{-8} \mathrm{M}$. The antiestrogens ICI 182,780 and 4-hydroxytamoxifen had no effect alone. When administered with $10^{-8} \mathrm{M} 17 \beta-\mathrm{E}_{2}$, ICI $182,780\left(10^{-7} \mathrm{M}\right)$ blocked completely the stimulatory effect of $17 \beta-\mathrm{E}_{2}$ and 4-hydroxytamoxifen $\left(10^{-8} \mathrm{M}\right)$ attenuated it from sixfold to about twofold.

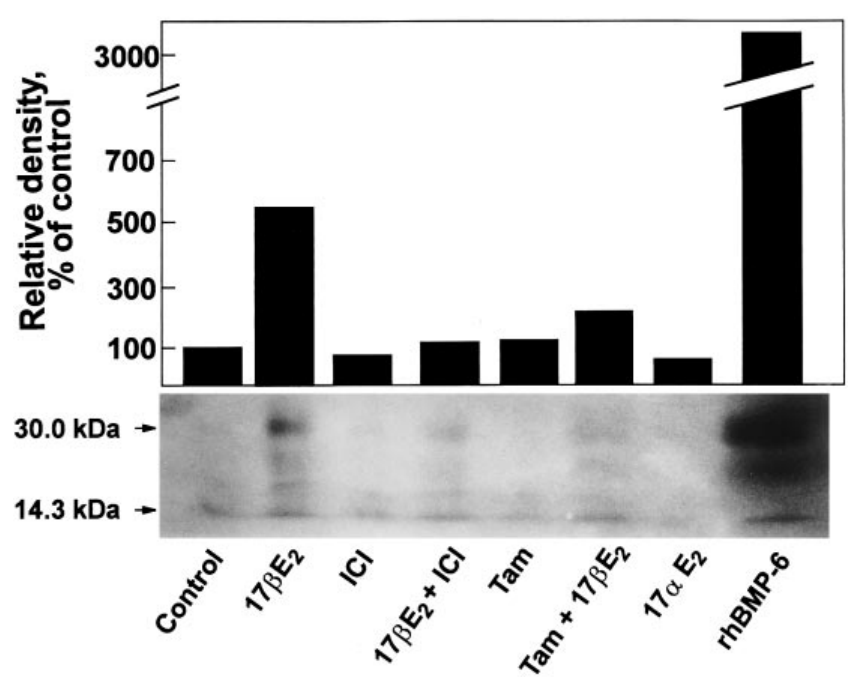

Figure 8. BMP-6 protein concentration in conditioned media of $\mathrm{hFOB/ER} 9$ cells, as measured by Western blot analysis. Cells were pretreated with ICI 182,780 and then cultured for $48 \mathrm{~h}$ in serum-free medium containing vehicle (control), 17 $\beta-\mathrm{E}_{2}$, ICI 182,780 (ICI), 4-hydroxytamoxifen (Tam), or $17 \alpha$-estradiol $\left(17 \alpha-E_{2}\right)$. The last lane contained $50 \mu \mathrm{g}$ of human recombinant BMP-6 (rhBMP-6) as a positive control. Lower panel shows the appearance of the immunoreactive bands. Size markers are shown at the left. Both the major immunoreactive band and the rhBMP-6 band ran on SDS-PAGE at $\sim 25 \mathrm{kD}$, most likely a glycosylated form of the mature monomer. A minor band of $\sim 15 \mathrm{kD}$ may represent the unglycosylated mature monomer. Upper panel shows the density of the bands relative to control as assessed by scanning densitometry. 


\section{Discussion}

Although the BMPs play important roles in skeletal development and in the differentiation of osteoblasts and chondroblasts, little is known about the regulation of their synthesis, and there have been no studies assessing the interaction of sex steroids with the BMPs. Using fetal osteoblastic cell lines that stably express the estrogen receptor gene, we found that estrogen stimulated the production of BMP-6 mRNA as assessed by RT-PCR and by Northern blot analysis and that this effect was specific because it was blocked by coadministration of antiestrogens. Sequence analysis of the PCR product confirmed that the estrogen-regulated gene was BMP-6. We also confirmed, by Western blot analysis of conditioned media, that estrogen treatment in vitro stimulated the secretion of BMP-6 protein. Interestingly, although expression of BMP-6 was found to be strongly regulated by estrogen, the related genes for TGF $\beta_{1}, \mathrm{TGF}_{2}$, and BMPs- 1 to -5 and -7 were not. The finding of selective stimulation of BMP- 6 by estrogen suggests that this process may be physiologically important. In view of the close structural and functional relationships between TGF and BMP, it may have been predicted that their synthesis would be similarly regulated. Indeed, the failure to detect induction of TGF $\beta_{1}$ mRNA by estrogen in hFOB/ER cells conflicts with previous findings in normal adult human osteoblast cells (8). The reason for the lack of TGF $\beta$ induction by estrogen in our cells is unclear but may relate to differences between fetal and adult osteoblasts. Alternatively, whereas both transcriptional and posttranscriptional regulation of TGF synthesis by estrogen has been observed in osteoblasts from adult bone, regulation in $\mathrm{hFOB} / \mathrm{ER}$ cells may be predominantly posttranscriptional.

In principle, the stimulation of BMP-6 by estrogen could contribute to any or all of the actions of estrogen on bone and cartilage cells. In the adult, estrogen acts to maintain bone mass by regulating bone remodeling and turnover (1). However, in the fetus and in the growing skeleton of the child and adolescent, it acts on both bone and cartilage cells to regulate endochondral bone formation. Fetal osteoblasts contain ER (37) and thus presumably respond to estrogen. Also, estradiol acts directly on chondrocytes in vitro to stimulate matrix synthesis (38). Both ER gene deletion (knockout) mice (39) and a human with a null mutation of the $E R$ gene (40) were found to have open epiphyseal growth plates. ER are present within the proliferating and hypertrophic zones of the epiphyseal cartilage of young rodents (41) and human fetuses (42).

Thus far, it has not been possible to distinguish clearly between the action of BMP-6 and that of other members of the BMP family. BMP-2, $-3,-4,-6$, and -7 all can induce the local formation of ectopic bone and cartilage when injected into subcutaneous or muscle tissue of rats $(33,43)$. BMP- $-2,-4$, and -6 promote the differentiation of multipotential mesenchymal cells along the osteoblast lineage (44-46) as well as stimulate the production of bone nodules in fetal rat calvarial cell cultures (47). Despite these general similarities, the existence of the large number of BMPs in itself implies that each one may perform related but distinct function(s), perhaps acting predominantly on different mesenchymal lineages (48), on different stages of development or cell differentiation (49), or even on different embryonic segments (14). However, the often overlapping pattern of production of certain BMPs during embryonic development also implies a degree of functional redundancy.
Although BMP-6 mRNA and protein have been detected in skeletal tissues as well as in nonskeletal tissues such as brain, skin, and fracture callus, in both embryos and adults, BMP-6 differs from other members of the BMP family by its concentration in cartilage of the fetus. In situ hybridization studies have localized mRNAs for various BMPs to different stages of fetal skeletal development. Thus, BMP-2 and -4 localize to the ectodermal ridge and, later, to the underlying mesenchyme $(15,16)$, and BMP-2 and the growth/differentiation factor (GDF)-5 localize to the differentiating precartilaginous mesenchyme $(15,50)$. In contrast, production of BMP-6 mRNA in the skeleton is localized to hypertrophic cartilage during skeletal development but not to perichondrium, periosteum, or bone (15). By immunocytochemical studies, BMP-6 protein was found to localize to matrix and cells of hypertrophic cartilage (33). Although the genes for BMP-7 and GDF-6 are expressed in hypertrophic cartilage, these are also expressed in perichondrium, periosteum, and centers of ossification (50, 51). Thus, although other BMPs besides BMP-6 are produced in hypertrophic cartilage during skeletal development, the highly restricted localization of BMP-6 to this tissue is consistent with a role in the modulation of endochondral bone formation. Because ER are also found in hypertrophic cartilage and because estrogen is required for growth plate closure in the immature skeleton, it is possible that at least some of the paracrine/autocrine actions of estrogen at this site are mediated by its effect on stimulating BMP-6. Thus far, however, we have demonstrated this regulation only in osteoblastic cells, and further studies will be required to test this hypothesis explicitly.

Because the hFOB/ER cell lines that were used in this study have a phenotype that closely resembles that of the mature osteoblast $(21,22)$, the demonstration that estrogen increases the secretion of BMP-6 suggests a possible role for BMP-6 in modulating bone remodeling in the adult skeleton, a process that requires recruitment, proliferation, and subsequent differentiation of osteoprogenitor cells. However, the founder cells of the hFOB/ER cell lines were fetal osteoblasts. Therefore, we cannot exclude the possibility that some of the stimulatory effect of estrogen on BMP-6 production is limited to fetal bone cells. The differentiation of osteoblasts in cultures of fetal rat calvaria-derived cells, measured by the bone nodule formation assay, is stimulated by several BMPs including BMP-6 (47, 52). Interestingly, in these cultures glucocorticoids selectively increase production of BMP-6 (36), an effect we have also observed in primary cultures of human bone marrow stromal cells (unpublished observations). Moreover, using antisense oligonucleotides to BMP-6, the glucocorticoid-stimulated development of mineralized bone nodules was found to be mediated by BMP-6 (36). Therefore, the selective regulation of BMP-6 by two osteotropic hormones (estrogen and glucocorticoid) strongly suggests that BMP-6 may play a key role in early stages of osteoblast differentiation and bone development. The effect of BMP-6 on proliferation and differentiation of the hFOB/ER cell lines has so far not been tested, but estrogen treatment, in addition to stimulating production of BMP-6, inhibits the proliferation of hFOB/ER9 cells and enhances certain differentiated osteoblast phenotypic markers $(10,25)$. It would therefore be of interest to determine whether BMP-6 can reproduce some or all of these estrogenic actions.

Various cell types overexpressing exogenous ER have frequently shown paradoxical responses to estrogen and atypical 
gene activation (53). However, our findings that BMP-6 was similarly regulated by estrogen in both hFOB/ER3 cells (possessing only $\sim 800 \mathrm{ER}$ per nucleus) and hFOB/ER9 cells (which possess $\sim 3,900$ ER per nucleus, comparable to receptor levels in reproductive tissue) is strong evidence to support our belief that the regulation of BMP- 6 by estrogen represents a novel and potentially important effect. Indeed, the ER level in $\mathrm{hFOB/ER} 3$ cells lies within the range for endogenous ER expression reported in normal human trabecular osteoblastlike cells $(\sim 1,600$ binding sites per cell) and ROS 17/2.8 (200500 sites per cell) in which estrogen responses have both been observed $(2,3,8)$. Furthermore, estrogen induction of the progesterone receptor gene has been observed in both hFOB/ ER cell lines; a classical estrogenic response common to all ER-positive tissues. These and other estrogen responses elicited by the $\mathrm{hFOB} / \mathrm{ER}$ cells, taken together, lead us to believe that the regulation of BMP-6 by estrogen may be physiologically relevant.

In conclusion, we have demonstrated that estrogen selectively increases the production of BMP-6, but not other BMPs, in estrogen-responsive, highly differentiated osteoblastic cell lines of fetal origin. Thus, we speculate that some of the recognized effects of estrogen on the skeleton could be mediated by increased production of BMP-6, which may then act in a paracrine/autocrine fashion to modulate the differentiation of uncommitted progenitors to osteoblasts and, in the immature skeleton, to chondrocytes.

\section{Acknowledgments}

The authors are indebted to Drs. S.A. Harris, M. Subramaniam, and S. Khosla, and K.C. Hicok for their valuable suggestions and advice during the course of these studies. We also thank Nurit Geller for assistance in analysis of the data.

This work was supported by National Institutes of Health grant AG-04875. Dr. Hofbauer is a recipient of a postgraduate fellowship from the Deutsche Forschungsgemeinschaft (Ho 1875/1-1).

\section{References}

1. Turner, R.T., G.L. Evans, and G.K. Wakley. 1993. Mechanism of action of estrogen on cancellous bone balance in tibiae of ovariectomized growing rats: inhibition of indices of formation and resorption. J. Bone Miner. Res. 8: 359-366.

2. Komm, B.S., C.M. Terpening, D.J. Benz, K.A. Graeme, B.W. O’Malley, and M.R. Haussler. 1988. Estrogen binding sites, receptor mRNA, and biologic response in osteoblast-like osteosarcoma cells. Science. 241:81-84.

3. Eriksen, E.F., D.S. Colvard, N.J. Berg, M.L. Graham, K.G. Mann, T.C. Spelsberg, and B.L. Riggs. 1988. Evidence of estrogen receptors in normal human osteoblast-like cells. Science. 241:84-86.

4. Oursler, M.J., P. Osdoby, J. Pyfferoen, B.L. Riggs, and T. Spelsberg. 1991. Avian osteoclasts as estrogen target cells. Proc. Natl. Acad. Sci. USA. 88: 6613-6617

5. Oursler, M.J., L. Pederson, L. Fitzpatrick, and B.L. Riggs. 1994. Human giant cell tumors of the bone (osteoclastomas) are estrogen target cells. Proc. Natl. Acad. Sci. USA. 91:5227-5231.

6. Kimble, R.B., A.B. Matayoshi, J.L. Vannice, V.T. Kung, C. Williams, and R. Pacifici. 1995. Simultaneous block of interleukin-1 and tumor necrosis factor is required to completely prevent bone loss in the early postovariectomy period. Endocrinology. 136:3054-3061.

7. Manolagas, S.C., and R.L. Jilka. 1995. Bone marrow, cytokines, and bone remodeling: emerging insights into the pathophysiology of osteoporosis. $N$. Engl. J. Med. 332:305-311.

8. Oursler, M.J., C. Cortese, P.E. Keeting, M.A. Anderson, S.K. Bonde, B.L. Riggs, and T.C. Spelsberg. 1991. Modulation of transforming growth factor- $\beta$ production in normal human osteoblast-like cells by $17 \beta$-estradiol and parathyroid hormone. Endocrinology. 129:3313-3320.

9. Ernst, M., J.K. Heath, and G.A. Rodan. 1989. Estradiol effects on proliferation, messenger ribonucleic acid for collagen and insulin-like growth factor-
I, and parathyroid hormone-stimulated adenylate cyclase activity in osteoblastic cells from calvariae and long bones. Endocrinology. 125:825-833.

10. Kassem, M., R. Okazaki, D. DeLeon, S.A. Harris, J.A. Robinson, T.C. Spelsberg, C.A. Conover, and B.L. Riggs. 1996. Potential mechanism of estrogen-mediated decrease in bone formation: estrogen increases production of inhibitory insulin-like growth factor binding protein-4. Proc. Assoc. Am. Physicians. 108:155-164.

11. Kessler, E., K. Takahara, L. Biniaminov, M. Brusel, and D.S. Greenspan. 1996. Bone morphogenetic protein-1: the type I procollagen C-proteinase. Science. 271:360-362.

12. Wozney, J.M., V. Rosen, A.J. Celeste, L.M. Mitsock, M.J. Whitters, R.W. Kriz, R.M. Hewick, and E.A. Wang. 1988. Novel regulators of bone formation: molecular clones and activities. Science. 242:1528-1534

13. Wang, E.A., V. Rosen, J.S. D'Alessandro, M. Bauduy, P. Cordes, T. Harada, D.I. Israel, R.M. Hewick, K.M. Kerns, P. LaPan, et al. 1990. Recombinant human bone morphogenetic protein induces bone formation. Proc. Natl. Acad. Sci. USA. 87:2220-2224.

14. Kingsley, D.M. 1994. What do BMPs do in mammals? Clues from the mouse short-ear mutation. Trends Genet. 10:16-21.

15. Lyons, K.M., R.W. Pelton, and B.L. Hogan. 1989. Patterns of expression of murine Vgr-1 and BMP-2a RNA suggest that TGFß-like genes co-ordinately regulate aspects of embryonic development. Genes Dev. 3:1657-1668.

16. Jones, C.M., K.M. Lyons, and B.L.M. Hogan. 1991. Involvement of bone morphogenetic protein-4 (BMP-4) and Vgr-1 in morphogenesis and neurogenesis in the mouse. Development (Camb.) 111:531-542.

17. Rosen, V., J. Nove, J.J. Song, R.S. Thies, K. Cox, and J.M. Wozney. 1994. Responsiveness of clonal limb bud cell lines to BMP-2 reveals a sequential relationship between cartilage and bone phenotypes. J. Bone Miner. Res. 9: 1759-1768.

18. Thies, R.S., M. Bauduy, B.A. Ashton, L. Kurtzberg, J.M. Wozney, and V. Rosen. 1992. Recombinant human bone morphogenetic protein-2 induces differentiation in W-20-17 stromal cells. Endocrinology. 130:1318-1324.

19. Amedee, J., R. Bareille, F. Rouais, N. Cunningham, H. Reddi, and M.F. Harmand. 1994. Osteogenin (BMP-3) inhibits proliferation and stimulates differentiation of osteoprogenitors in human bone marrow. Differentiation. 58: $157-164$.

20. Vukicevic, S., F.P. Luyten, and A.H. Reddi. 1989. Stimulation of expression of osteogenic and chondrogenic phenotypes in vitro by osteogenin. Proc. Natl. Acad. Sci. USA. 86:8793-8797.

21. Harris, S.A., R.J. Enger, B.L. Riggs, and T.C. Spelsberg. 1995. Development and characterization of a conditionally immortalized human fetal osteoblastic cell line. J. Bone Miner. Res. 10:178-186.

22. Harris, S., K.R. Tau, R.J. Enger, D.O. Toft, B.L. Riggs, and T.C. Spelsberg. 1995. Estrogen response in the hFOB1.19 human fetal osteoblastic cell line stably transfected with the human estrogen receptor gene. J. Cell. Biochem. 59:193-201.

23. Spelsberg, T.C., M.L. Graham, N.J. Berg, T. Umehara, E. Riehl, C.B. Coulam, J.N. Ingle. 1987. A nuclear binding assay to assess the biological activity of steroid receptors in isolated animal and human tissues. Endocrinology. 121:631-644.

24. Colvard, D.S., W.R. Jankus, N.J. Berg, M.L. Graham, N.-S. Jiang, J.N. Ingle, and T.C. Spelsberg. 1988. Microassay for nuclear binding of steroid receptors with use of intact cells from small samples of avian and human tissues. Clin. Chem. 34:363-369.

25. Robinson, J.A., S.A. Harris, B.L. Riggs, and T.C. Spelsberg. 1997. Estrogen regulation of human osteoblast cell proliferation and differentiation. Endocrinology. 138:2919-2927.

26. Parker, M.G. 1993. Action of 'pure' antiestrogens in inhibiting estrogen receptor action. Breast Cancer Res. Treat. 26:131-137.

27. Celeste, A.J., J.A. Iannazzi, R.C. Taylor, R.M. Hewick, V. Rosen, E.A. Wang, and J.M. Wozney. 1990. Identification of transforming growth factor- $\beta$ family members present in bone-inductive protein purified from bovine bone. Proc. Natl. Acad. Sci. USA. 87:9843-9847.

28. Chomczynski, P., and N. Sacchi. 1987. Single-step method of RNA isolation by acid guanidinium thiocyanate-phenol-chloroform extraction. Anal. Biochem. 162:156-159.

29. Laemmli, U.K. 1970. Cleavage of structural proteins during the assembly of the head of bacteriophage T4. Nature. 227:680-685.

30. Katzenellenbogen, J.A., B.W. O'Malley, and B.S. Katzenellenbogen. 1996. Tripartite steroid hormone receptor pharmacology: Interaction with multiple effector sites as a basis for the cell- and promoter-specific action of these hormones. Mol. Endocrinol. 10:119-131.

31. Schuchard, M., J.P. Landers, N. Punkay-Sandhu, and T.C. Spelsberg. 1993. Steroid hormone regulation of nuclear proto-oncogenes. Endocr. Rev. 14: 659-669.

32. Weisz, A., and F. Bresciani. 1988. Estrogen induces expression of c-fos and c-myc protooncogenes in rat uterus. Mol. Endocrinol. 2:816-824.

33. Gitelman, S.E., M.S. Kobrin, J.-Q. Ye, A.R. Lopez, A. Lee, and R. Derynck. 1994. Recombinant Vgr-1/BMP 6-expressing tumors induce fibrosis and endochondral bone formation in vivo. J. Cell Biol. 126:1595-1609.

34. Carey, D.E., and X. Liu. 1995. Expression of bone morphogenetic protein-6 messenger RNA in bovine growth plate chondrocytes of different size. $J$. 
Bone Miner. Res. 10:401-405

35. Wall, N.A., M. Blessing, C.V.E. Wright, and B.L.M. Hogan. 1993. Biosynthesis and in vivo localization of the decapentaplegic-Vg-related protein, DVR-6 (bone morphogenetic protein-6). J. Cell Biol. 120:493-502.

36. Boden, S.D., G. Hair, L. Titus, M. Racine, K. McCuaig, J.M. Wozney, and M.S. Nanes. 1997. Glucocorticoid-induced differentiation of fetal rat calvarial osteoblasts is mediated by bone morphogenetic protein-6. Endocrinology. 138:2820-2828.

37. Komm, B., R. Henderson, P. Bodine, J. Green, J. Lian, and G. Stein. 1996. The estrogen receptor is developmentally up-regulated during osteoblast differentiation. J. Bone Miner. Res. 11(Suppl.1):S258.

38. Corvol, M.-T., A. Carrascosa, L. Tsagris, O. Blanchard, and R. Rappaport. 1987. Evidence for a direct in vitro action of sex steroids on rabbit cartilage cells during skeletal growth: influence of age and sex. Endocrinology. 120: $1422-1429$.

39. Korach, K.S. 1994. Insights from the study of animals lacking functional estrogen receptor. Science. 266:1524-1527.

40. Smith, E.P. J. Boyd, G.R. Frank, H. Takahashi, R.M. Cohen, B. Specker, T.C. Williams, D.B. Lubahn, and K.S. Korach. 1994. Estrogen resistance caused by a mutation in the estrogen receptor gene in a man. N. Engl. J. Med. 331:1056-1061.

41. Pinus, H., A. Ornoy, N. Patlas, P. Yaffe, and Z. Schwartz. 1993. Specific $\beta$-estradiol binding in cartilage and serum from young mice and rats is age dependent. Connect. Tissue Res. 30:85-98.

42. Ben-Hur, H., G. Mor, I. Blickstein, I. Likhman, F. Kohen, R. Dgani, V. Insler, P. Yaffe, and A. Ornoy. 1993. Localization of estrogen receptors in long bones and vertebrae of human fetuses. Calcif. Tissue Int. 53:91-96.

43. Reddi, A.H., and N.S. Cunningham. 1993. Initiation and promotion of bone differentiation by bone morphogenetic proteins. J. Bone Miner. Res. 8 (Suppl.2):S499-S502.

44. Wang, E.A., D.I. Israel, S. Kelly, and D.P. Luxenberg. 1993. Bone morphogenetic protein-2 causes commitment and differentiation in C3H10T1/2 and 3 T3 cells. Growth Factors. 9:57-71.
45. Ahrens, M., T. Ankenbauer, D. Schroder, A. Hollnagel, H. Mayer, and G. Gross. 1993. Expression of human bone morphogenetic proteins -2 or -4 in murine mesenchymal C3H10T1/2 cells induces differentiation into distinct mesenchymal cell lineages. DNA Cell Biol. 12:871-880.

46. Gitelman, S.E., M. Kirk, J.Q. Ye, E.H. Filvaroff, A.J. Kahn, and R. Deryack. 1995. Vgr-1/BMP-6 induces osteoblastic differentiation of pluripotential mesenchymal cells. Cell Growth Diff. 6:827-836.

47. Hughes, F.J., J. Collyer, M. Stanfield, and S.A. Goodman. 1995. The effects of BMP-2, -4 and -6 on differentiation of rat osteoblast cells in vitro. Endocrinology. 136:2671-2677.

48. Lyons, K.M., R.W. Pelton, and B.L.M. Hogan. 1990. Organogenesis and pattern formation in the mouse: RNA distribution patterns suggest a role for bone morphogenetic protein-2A (BMP-2A). Development. 109:833-844.

49. Wozney, J.M. 1993. Bone morphogenetic proteins and their gene expression. In Cellular and Molecular Biology of Bone. M. Noda, editor. Academic Press, San Diego, CA. 131-167.

50. Chang, S.C., B. Hoang, J.T. Thomas, S. Vukicevic, F.P. Luyten, N.J. Ryba, C.A. Kozak, A.H. Reddi, and M. Moos. 1994. Cartilage-derived morphogenetic proteins. New members of the TGF $\beta$ superfamily predominantly expressed in long bones during human embryonic development. J. Biol. Chem. 269:28227-28234.

51. Vukicevic, S., V. Latin, P. Chen, R. Batorsky, A.H. Reddi, and T.K. Sampath. 1994. Localization of OP-1 (BMP-7) during human embryonic development: high affinity binding to basement membranes. Biochem. Biophys. Res. Commun. 198:693-700.

52. Boden, S.D., K. McCuaig, G. Hair, M. Racine, L. Titus, J.M. Wozney, and M.S. Nanes. 1996. Differential effects and glucocorticoid potentiation of bone morphogenetic protein action during rat osteoblast differentiation in vitro. Endocrinology. 137:3401-3407.

53. Levenson, A.S., and V.C. Jordan. 1994. Transfection of human estrogen receptor (ER) cDNA into ER-negative mammalian cells. J. Steroid Biochem Mol. Biol. 51:229-239. 